Dr Agnieszka PIEKUTOWSKA

Wydział Ekonomii i Zarządzania, Uniwersytet w Białymstoku e-mail: piekutowska@uwb.edu.pl

ORCID: 0000-0001-7923-9484

Dr Monika FIEDORCZUK

Wydział Ekonomii i Zarządzania, Uniwersytet w Białymstoku e-mail: monika.fiedorczuk@uwb.edu.pl

ORCID: 0000-0002-8895-0793

DOI: $10.15290 /$ oes.2019.03.97.05

\title{
RELACJE MIĘDZY WYMIANĄ HANDLOWĄ A MIGRACJAMI W FEDERACJI ROSYJSKIEJ ${ }^{1}$
}

\begin{abstract}
Streszczenie
Cel - Głównym celem opracowania jest zbadanie relacji między handlem zagranicznym a migracjami w Federacji Rosyjskiej oraz próba wyjaśnienia przyczyn wykazanych relacji, w tym na gruncie wybranych nurtów teoretycznych.

Metoda badan - W artykule zastosowano analizę danych statystycznych, dotyczących obrotów handlowych i migracji dla Rosji w latach 2001-2017.

Wnioski - Przeprowadzone badanie wykazało, iż w przypadku Federacji Rosyjskiej wyniki badań wskazują na substytucyjny charakter relacji między analizowanymi kategoriami.

Oryginalność / wartość - Badania zależności między handlem zagranicznym a migracjami nie były dotąd przeprowadzane w odniesieniu do gospodarki Rosji. Mogą stanowić ważny wkład do dalszych badań nad migracjami międzynarodowymi.
\end{abstract}

Słowa kluczowe: handel zagraniczny, emigracja, imigracja, integracja gospodarcza

\section{RELATIONS BETWEEN FOREIGN TRADE AND MIGRATIONS IN THE RUSSIAN FEDERATION}

\section{Summary}

Purpose - The main aim of the study is to examine the relationship between foreign trade and migration in the Russian Federation, and an attempt to explain the reasons for revealed relationships, inter alia - on the basis of selected theories in this respect.

Research method - The study was based on the statistical analysis of statistical data on trade and migration in the Russian Federation between 2001 and 2017.

Results - The study revealed that in the case of the Russian Federation, trade and migration are substitutes.

1 Artykuł wpłynał 2 stycznia 2019 r., zaakceptowano 6 maja 2019 r.

Article received 2 January 2019, accepted 6 May 2019. 
Originality / value - Research on the relationship between foreign trade and migration has not been carried out so far in relation to Russia. Thus, the study can be a contribution to further research on international migration.

Key words: foreign trade, emigration, immigration, economic integration

JEL classification: F11, F12, F16

\section{Wstęp}

Proces globalizacji faworyzuje przepływ towarów, usług i kapitału bardziej niż przepływ siły roboczej. Ponadto znoszenie ograniczeń w obszarze międzynarodowego handlu oraz przepływów kapitału zachodzi szybciej niż znoszenie barier migracji. O ile jest zgoda co do korzyści wynikających z liberalizacji wymiany handlowej, to konsensus ten nie rozciąga się na migracje międzynarodowe [Solimano, 2001, s. 2,10].

Ważna przesłanka, uzasadniająca podjęcie rozważań nad charakterem relacji wymiany handlowej i siły roboczej, jest ukazanie możliwych efektów w przypadku regionalnej liberalizacji handlu. Tworzeniu regionalnych ugrupowań integracyjnych towarzyszą oczekiwania, m.in. w zakresie wpływu liberalizacji handlu na ceny czynników produkcji (w tym płace) i migracje. Relacja między wymianą handlową a migracjami może mieć przy tym z jednej strony charakter komplementarny, a z drugiej - substytucyjny. Argument o substytucyjnym charakterze wymiany handlowej i migracji zdaje się pozostawać w powszechnym przekonaniu polityków, którzy drogą liberalizacji handlu liczą na zmniejszenie presji migracyjnej, której nie są w stanie zatrzymać restrykcyjne polityki migracyjne.

Celem artykułu jest próba odpowiedzi na pytanie badawcze, czy w przypadku Federacji Rosyjskiej relacje między handlem zagranicznym a migracjami mają charakter substytucyjny czy komplementarny. Podjęte badanie jest elementem projektu badawczego, mającego na celu analizę migracji międzynarodowych w krajach Europy Środkowej i Wschodniej.

\section{Relacje między handlem międzynarodowym a migracjami w wybranych nurtach teoretycznych}

Praca i jej mobilność międzynarodowa stanowi przedmiot zarówno teorii handlu, jak i teorii migracji. Teoria obfitości zasobów Heckschera-Ohlina-Samuelsona (H-O-S) uznaje, że podstawą wymiany międzynarodowej jest różne wyposażenie państw w czynniki produkcji. Przy przyjętych założeniach kraj będzie eksportował te towary, do wytworzenia których wymagane jest istotne zużycie czynnika obfitego. Jednocześnie, na skutek wymiany handlowej nastapi wyrównanie cen czynników produkcji pomiędzy krajami. Zatem nawet $\mathrm{w}$ sytuacji braku migracji pomiędzy krajami dojdzie, za pośrednictwem handlu, do wyrównania w nich płac [Borjas, 1989, s. 459]. To natomiast oznaczać będzie, że zniknie przesłanka do mobilności 
siły roboczej. Praca jest eksportowana w dobrach podlegających wymianie. Stąd wymiana handlowa w świetle omawianej teorii ma substytucyjny charakter w stosunku do migracji. Analogicznie, jeśli migracje siły roboczej doprowadzą do wyrównania ceny pracy, nie będzie przesłanek do wymiany handlowej [Melchor del Río, Thorwarth, 2007, s. 4].

Z tezą o substytucyjnym charakterze handlu międzynarodowego i migracji zgadza się R.A. Mundell. Uważa on, że w konsekwencji takiej relacji wzrost ograniczeń w handlu będzie stymulował przepływy czynników produkcji [Mundell, 1957, s. 321]. Jak zauważaja jednak P.R. Krugman i M. Obsfeld [2007, s. 231], handel nie jest doskonałym substytutem międzynarodowego przepływu czynników produkcji. Nieobserwowany w rzeczywistości proces pełnego wyrównywania się cen czynników produkcji wynika m.in. z naturalnych, jak i sztucznych barier dla wymiany handlowej czy zróżnicowanych technologii.

Usuwając założenie przyjęte w teorii H-O-S o jednakowych technologiach stosowanych przez dwa kraje, J.R. Markusen dowodzi, że handel i migracje międzynarodowe moga mieć komplementarny charakter [Melchor del Río, Thorwarth, 2007, s. 4]. Przyjmując założenie o jednakowym wyposażeniu w czynniki wytwórcze dwóch krajów, za podstawę do wymiany handlowej uznaje zróżnicowaną technologię, która doprowadza do wzrostu zasobów czynnika intensywniej wykorzystywanego w produkcji eksportowej (na skutek migracji czynników zgodnie z różnicami w ich krańcowych produktywnościach). Obfite wyposażenie w czynnik produkcji jest zatem według J.R. Markusena rezultatem przepływu czynników wytwórczych [Mińska-Struzik, 2004, s. 31].

Przyjmując za punkt wyjścia teorię H-O-S, zgodnie z którą liberalizacja handlu doprowadzi do wzrostu cen czynnika obfitego w danym kraju, warto zauważyć, iż dla państw rozwijających się liberalizacja oznaczałaby wzrost wynagrodzeń niewykwalifikowanej siły roboczej, w który to czynnik państwa te wyposażone są w sposób obfity [Williamson, 1997, s. 119]. W takich okolicznościach zmniejszyłaby się presja emigracyjna pracowników nisko wykwalifikowanych. Badania empiryczne nie potwierdzają takiego procesu [Davis, 1993, s. 1]. Jednocześnie spadek wynagrodzeń pracowników niewykwalifikowanych w państwach rozwiniętych (np. USA) przypisywany był konkurencji ze strony dóbr importowanych z krajów nowo uprzemysłowionych [Grimwade, 2003, s. 269]. Usunięcie założenia przyjętego w teorii H-O-S o jednorodności pracy prowadzi do niejednoznacznych wniosków w zakresie wpływu handlu na migracje (w drodze zwiększania bądź zmniejszania różnic w poziomie płac).

Usunięcie kolejnego założenia przyjętego w teorii H-O-S (że przeciętne koszty produkcji nie są zależne od skali produkcji) także zmienia charakter relacji pomiędzy wymianą handlową a migracjami. Jeżeli przeciętne koszty produkcji spadają wraz ze wzrostem skali produkcji, migracje i handel stają się komplementarne. Jak wyjaśnia P. Martin [2003, s. 12, 14] na przykładzie USA i Meksyku, wzrost produkcji np. w USA zwiększy popyt na imigrację z Meksyku. Do wniosku o komplementarnym charakterze migracji i handlu opierającego się na korzyściach skali dochodzi też J.R. Markusen, który zakłada ponadto zewnętrzne korzyści skali, analiza więc odnosi 
się do konkurencji doskonałej [Schiff, 1996, s. 5]. Przyjmując założenie o wewnętrznych korzyściach skali P.R. Krugman [1979, s. 477-478] dochodzi do wniosku, że handel międzynarodowy oparty na korzyściach skali i migracje są w stosunku do siebie substytucyjne.

Podejmując próby konceptualizacji nieliniowego związku pomiędzy procesami rozwojowymi a skalą emigracji z danego kraju, P. Martin i E. Taylor wprowadzili pojęcie tzw. garbu migracyjnego (migration hump) dowodząc, że wraz z rozwojem gospodarczym w danym kraju i zmniejszeniem różnic dochodowych w pierwszym okresie dochodzi do istotnego wzrostu emigracji, a w późniejszych fazach wzrostu gospodarczego do spadku emigracji z tego kraju. Stąd relację między wzrostem wynagrodzeń a skala emigracji w danym kraju odzwierciedla krzywa o kształcie odwróconej litery U (inverted U-curve) [de Haas, 2006, s. 4-5].

Warto wskazać na jedną z przyczyn zwiększonej mobilności międzynarodowej w pierwszym okresie wzrostu gospodarczego. Jak wskazuje M. Shiff, przyczyna ta wiąże się z kosztami migracji (koszty podróży czy wydatki związane z pobytem w państwie docelowym do czasu znalezienia zatrudnienia). Przy niskim poziomie dochodu migranci mogą nie być w stanie pokryć tych kosztów. Jeżeli jednak dojdzie do wzrostu wynagrodzeń, który pozwoli na pokrycie kosztów związanych z wyjazdem, dojdzie do wzrostu emigracji. Ostatecznie, uwzględnienie kosztów migracji w teorii H-O-S może zmienić charakter relacji między handlem a migracjami zjawiska te będa komplementarne co najmniej w krótkim okresie (substytucyjne w długim okresie) [Schiff, 1994, s. 2-7]. Podobnie uważa E.J. Taylor [2006], zdaniem którego integracja $\mathrm{w}$ zakresie wymiany handlowej powoduje zwiększenie presji migracyjnej w krótkim okresie i zmniejszenie tej presji w długim okresie.

Dotychczasowa analiza relacji między handlem a migracjami skoncentrowana była głównie na ukazaniu możliwego wpływu handlu na migracje. Ukazanie pełnej relacji pomiędzy nimi implikuje także analizę wpływu migracji na wymianę handlowa. Migracje moga prowadzić do zmiany wolumenu wymiany handlowej. Jak zauważają M. Genc, M. Gheasi, P. Nijkamp, J. Poot [2011, s. 1] wzrost populacji indukowany imigracja prowadzi do wzrostu popytu, również na produkty importowane. Na skutek imigracji dojść może też do wzrostu eksportu, jeżeli zatrudnienie imigrantów w produkcji eksportowej prowadzi do zmniejszenia kosztów produkcji. Wzrost eksportu wynikać może także z wykorzystania istniejących sieci, znajomości rynku, języka i kultury państwa pochodzenia imigrantów.

\section{Handel międzynarodowy a migracje - przegląd badań empirycznych}

Przegląd wyników badań empirycznych nie pozwala na przyjęcie jednoznacznego wniosku w zakresie charakteru relacji pomiędzy wymianą handlową a migracjami. Jednocześnie z badań $\mathrm{w}$ zakresie wpływu liberalizacji handlu na migracje wynika, że charakter relacji może zmieniać się w czasie: w krótkim okresie handel jest komplementarny wobec migracji, w długim może być substytucyjny [Mabrouk, 
2012, s. 241]. Zestawienie badań nad relacją między handlem a migracjami zawiera tabela 1.

TABELA 1

Handel i migracje: wyniki wybranych badań empirycznych

\begin{tabular}{|c|c|c|}
\hline $\begin{array}{l}\text { Autor } \\
\text { (Autorzy) } \\
\text { badania }\end{array}$ & Obszar badań & $\begin{array}{c}\text { Wyniki badań } \\
\text { w zakresie charakteru } \\
\text { relacji między } \\
\text { handlem } \\
\text { międzynarodowym } \\
\text { a migracjami }\end{array}$ \\
\hline Bruder & $\begin{array}{l}\text { Relacje między handlem a imigracją do Niemiec } \\
\text { w latach 1970-1988 }\end{array}$ & \multirow[t]{2}{*}{ Substytucyjny } \\
\hline Jacks, Tang & $\begin{array}{l}\text { Relacje między handlem a imigracją w Kanadzie } \\
\text { i USA w latach } 1870-2010\end{array}$ & \\
\hline $\begin{array}{l}\text { Baudassé, } \\
\text { Montalieu, } \\
\text { Rabaud }\end{array}$ & $\begin{array}{l}\text { Relacje między eksportem usług a imigracja z } \\
191 \text { krajów do } 20 \text { krajów OECD w latach } 2000 \text {, } \\
2005 \text { i } 2010\end{array}$ & \multirow[t]{4}{*}{ Komplementarny } \\
\hline Richards & $\begin{array}{l}\text { Wybrane państwa Południowej i Wschodniej } \\
\text { Azji oraz Ameryki Lacińskiej (w tym: Korea } \\
\text { Południowa, Tajwan, Singapur, Chile, Meksyk, } \\
\text { Argentyna, Boliwia, Kolumbia), w różnych } \\
\text { okresach drugiej połowy XX wieku }\end{array}$ & \\
\hline $\begin{array}{l}\text { Bryant, Genç, } \\
\text { Law }\end{array}$ & $\begin{array}{l}\text { Relacje między wymianą handlową a migracjami } \\
\text { w Nowej Zelandii w latach 1981-2001 }\end{array}$ & \\
\hline Mundra & $\begin{array}{l}\text { Relacje między wymianą handlową a migracjami } \\
\text { w USA w latach 1973-1980 }\end{array}$ & \\
\hline $\begin{array}{l}\text { Collins, } \\
\text { O'Rourke, } \\
\text { Williamson }\end{array}$ & $\begin{array}{l}\text { Relacje między handlem a migracjami w latach } \\
\text { 1870-1913 oraz 1919-1936 w odniesieniu do } \\
\text { następujących krajów: Australia, Kanada, USA, } \\
\text { Dania, Francja, Niemcy, Włochy, Norwegia, } \\
\text { Szwecja, Wielka Brytania }\end{array}$ & \multirow[t]{3}{*}{$\begin{array}{l}\text { Substytucyjny bądź } \\
\text { komplementarny }\end{array}$} \\
\hline Rotte, Vogler & $\begin{array}{l}\text { Migracje i handel między Niemcami a } 86 \\
\text { państwami wysyłającymi migrantów do tego } \\
\text { kraju z Afryki i Azji w latach 1981-1995 }\end{array}$ & \\
\hline Girma, Yu & $\begin{array}{l}\text { Wpływ migracji na handel między Wielką Bryta- } \\
\text { nią a } 26 \text { państwami należącymi do Wspólnoty } \\
\text { Narodów i } 22 \text { krajami spoza niej, w latach } \\
\text { 1981-1993 }\end{array}$ & \\
\hline
\end{tabular}

Źródło: [Mabrouk, 2012, s. 241; Bruder, 2004, s. 2-14; Jacks, Tang, 2018, s. 2-20; Baudassé $\mathrm{i}$ in., 2018, s. 2-17; Richards, 1993, s. 1-18; Bryant i in., 2005, s. 1-25; Mundra, 2005, s. 1-19; Collins i in., 1997; s. 1-25, Rotte, Vogler, 1998, s. 1-22; Girma, Yu, 2000, s. 1-20].

Szereg badań w zakresie wpływu liberalizacji handlu na ruchy migracyjne podjęto w odpowiedzi na tworzenie regionalnych ugrupowań integracyjnych, np. NAFTA. 
Zgodnie z przypuszczeniami P.L. Martina, wraz z utworzeniem NAFTA doszło do wzrostu emigracji z Meksyku do USA [Martin, 1993, s. 14; Delgado-Wise, Márquez Covarrubias, 2007, s. 665-666]. W świetle badań przeprowadzonych przez A.M. del Río i S. Thorwarth [2007] zwiększenie bilateralnej wymiany handlowej pomiędzy USA a Meksykiem doprowadziło do wzrostu emigracji nielegalnej z Meksyku. Badania przeprowadzone przez T.J. Hattona i J.G. Williamsona [2009, s. 23-24] w latach 1970-2004 potwierdziły wystapienie garbu migracyjnego w Meksyku (a także w innych 25 państw Ameryki Łacińskiej w tym okresie).

W przypadku Unii Europejskiej badania w zakresie wpływu liberalizacji handlowej na ruchy migracyjne podjęła (w oparciu o model grawitacyjny) $\mathrm{H}$. Lund. Wyniki analizy regresji za lata 1997-2001 wykazały pozytywna (i istotna) korelację między wymiana handlową a skalą migracji: wraz ze wzrostem importu rośnie imigracja [Lund, 2009, s. 33]. Jednocześnie, badania przeprowadzone przez J. Brudera dla Niemiec i głównych państw wysyłających do tego kraju (tj. Hiszpanii, Portugalii, Grecji, Włoch i Turcji) wykazały, że liberalizacji handlu towarzyszy spadek imigracji do Niemiec, zatem handel i migracje mają substytucyjny charakter. Jednakże wpływ handlu na imigrację nie był zbyt istotny - znacznie większy wpływ na kształtowanie imigracji do Niemiec wywierał istniejący zasób imigrantów z wymienionych państw wysyłających, którzy już przebywali w Niemczech (badania dotyczące lat 1970-1988) [Bruder, 2004, s. 12-13]. Przyjęcie dłuższej perspektywy ma istotne znaczenie: jak wynika $\mathrm{z}$ przeprowadzonej analizy teorii handlu $\mathrm{w}$ długim okresie może dojść do zmiany charakteru relacji pomiędzy wymianą handlowa a migracjami: $z$ komplementarnej na substytucyjną.

Z badań przeprowadzonych przez J.A. Dunlevy'ego i W.K. Hutchinsona [1999, s. 1043-1057], dotyczących wpływu imigracji do USA na import do tego państwa w okresie 40 lat poprzedzających wybuch I wojny światowej wynika, że imigracja miała charakter proimportowy, tzn. wraz ze wzrostem imigracji wzrastał import. Dodać należy, że w przeprowadzonej analizie regresji zmienna objaśniana (import) obejmowała wybrane kategorie produktów, które wiązały się z określonymi gustami imigrantów. Wyróżnienie ich pozwoliło pozytywnie zweryfikować hipotezę, że wzrost importu w związku z imigracją wynika między innymi z popytu imigrantów na określone produkty z państwa pochodzenia.

Do podobnych wniosków (o proimportowym charakterze imigracji) doszli P.H. Egger, M. von Ehrlich i D.R. Nelson. Koncentrując swoją analizę na migracjach w 27 krajach OECD (z i do 130 krajów) w 2000 r. wykazali, że import zwiększa się wraz z imigracją, a powyższy wniosek wyjaśnili w kontekście efektu powiększania rynku (na skutek imigracji). Jednoczenie Autorzy podkreślili, że zależność między wzrostem imigracji a wzrostem importu nie jest liniowa - na niskim poziomie imigracji import rośnie gwałtownie, po czym tempo jego wzrostu spada, a spadek ten następuje przy imigracji na poziomie 4000 imigrantów (przeciętnie dla analizowanych państw) [Egger i in., 2011, s. 1-16]. 


\section{Relacje między wymianą handlową a migracjami w Federacji Rosyjskiej}

W artykule dokonano ogólnej analizy kształtowania się relacji między wolumenem handlu zagranicznego i migracji w Federacji Rosyjskiej. Wybór kraju przyjętego do analizy nie jest przypadkowy: odczuwa on silne procesy migracyjne, włączony jest ponadto w procesy regionalnej integracji gospodarczej w ramach Euroazjatyckiej Unii Gospodarczej. Dotychczas badania odnoszące się do relacji między handlem a migracjami w odniesieniu do Federacji Rosyjskiej nie były podejmowane. W badaniach przyjęto za okres analizy lata 2001-2017, analizę podjęto wobec dynamiki wolumenu eksportu i importu oraz dynamiki emigracji i imigracji do Rosji.

W pierwszej kolejności zbadano kształtowanie się relacji między eksportem a emigracją i imigracją do Rosji. Warto odnotować znaczącą dynamikę wolumenu eksportu z Rosji w badanym okresie, zwłaszcza do 2008 r. (w powiązaniu z wysoką dynamiką wzrostu gospodarczego), która obniżyła się po kryzysie i można ją traktować jako jeden z przejawów stagnacji rosyjskiej gospodarki. Migracje z i do Rosji także wykazywały się znacznymi zmianami. Emigrację kształtowały m.in. wspomniane okresy zmiennej koniunktury, z kolei istotny wpływ na dynamikę imigracji wywarł proces liberalizacji dostępu do rosyjskiego rynku pracy ${ }^{2}$ [IEP, 2016, s. 325-330].

RYSUNEK 1

\section{Dynamika wolumenu eksportu i dynamika emigracji z Rosji w latach 2001-2017 (indeks; rok poprzedni $=100$ )}

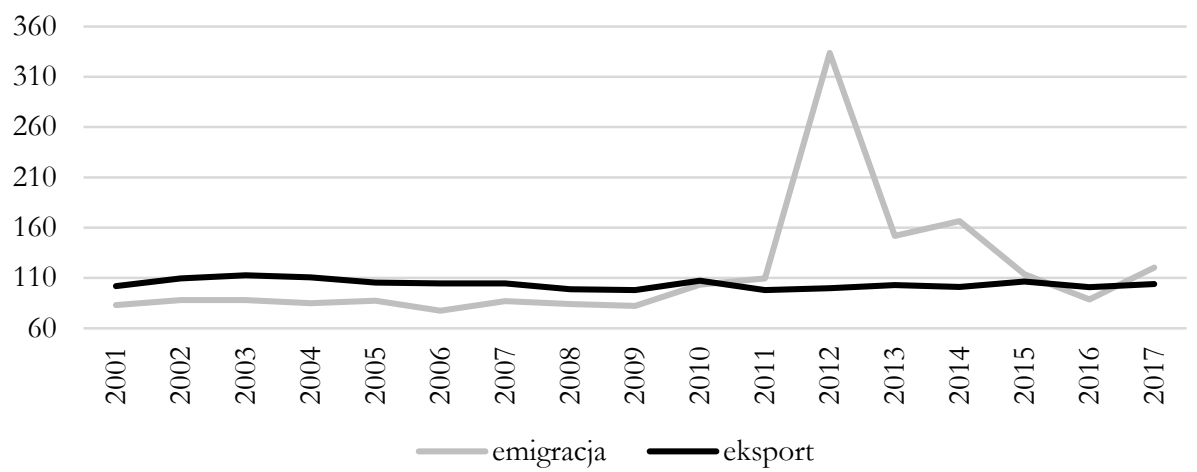

Źródło: opracowanie własne na podstawie [WTO, Rosstat].

Analiza relacji pomiędzy emigracja a eksportem z Rosji (rysunek 1) prowadzi do wniosku o ich substytucyjnym charakterze. Konieczne staje się jednak wyróżnienie

2 W 2012 r. przyjęto nową Koncepcję państwowej polityki migracyjnej Federacji Rosyjskiej do 2025 r., a 2015 r. przyniósł znaczące zmiany w obszarze pozwoleń na pracę w Rosji. Zniesiono bowiem obowiązek ich uzyskiwania dla obywateli z tzw. krajów bezwizowych (m.in. należących do Euroazjatyckiej Unii Gospodarczej). 
dwóch okresów (wniosek o substytucyjności emigracji i eksportu odnosi się do obu z nich). W 2011 r. dokonano rozszerzenia zakresu ewidencjonowania migrantów. Do 2011 r. dokumenty migrantów zarejestrowanych według miejsca przebywania niezależnie od okresu tego przebywania na terytorium FR nie były włączane do rejestru migrantów. Od 2011 r. w rejestr migrantów długookresowych włączone zostały również osoby przebywające na terytorium FR 9 miesięcy i więcej oraz osoby, które zostały wypisane z rejestru w związku z zakończeniem tego okresu [Rosstat, 2017, s. 202]. Z tego względu dane za lata 2001-2011 oraz 2012-2017 są nieporównywalne. Jednocześnie, można zauważyć, że w tym pierwszym okresie dynamika emigracji ustępowała dynamice wolumenu eksportu. Wiązać to można z wysoką dynamiką wzrostu gospodarczego Rosji, znaczącym wzrostem wartości eksportu, produkcji i inwestycji oraz rosnacym wówczas zapotrzebowaniem na siłę robocza, zarówno nisko, jak i wysoko wykwalifikowana. W takich okolicznościach zmniejszają się przesłanki do emigracji.

W drugim okresie analizy zauważyć można z kolei zwiększoną dynamikę emigracji z Rosji, której ustępowała dynamika wzrostu eksportu (wyjątkiem jest 2016 r.). W całym analizowanym okresie dynamika wolumenu eksportu i emigracji kształtowały się w odmiennym kierunku - kiedy eksport rósł istotnie, dynamika emigracji spadała - a kiedy dynamika eksportu zmniejszała się, emigracja wykazywała się wyższą dynamiką wzrostu. Sugeruje to substytucyjność w relacjach między badanymi zmiennymi.

Do podobnego wniosku skłania analiza dynamiki eksportu i imigracji (rysunek 2). W pierwszym okresie, z wyjątkiem lat 2005-2007, dynamika imigracji ustępowała dynamice eksportu. Z kolei na przestrzeni 2012-2017 r. imigracja rosła szybciej niż eksport (wyjątek stanowią lata 2015 i 2016).

RYSUNEK 2

Dynamika wolumenu eksportu i dynamika imigracji do Rosji w latach 2001-2017 (indeks; rok poprzedni $=100$ )

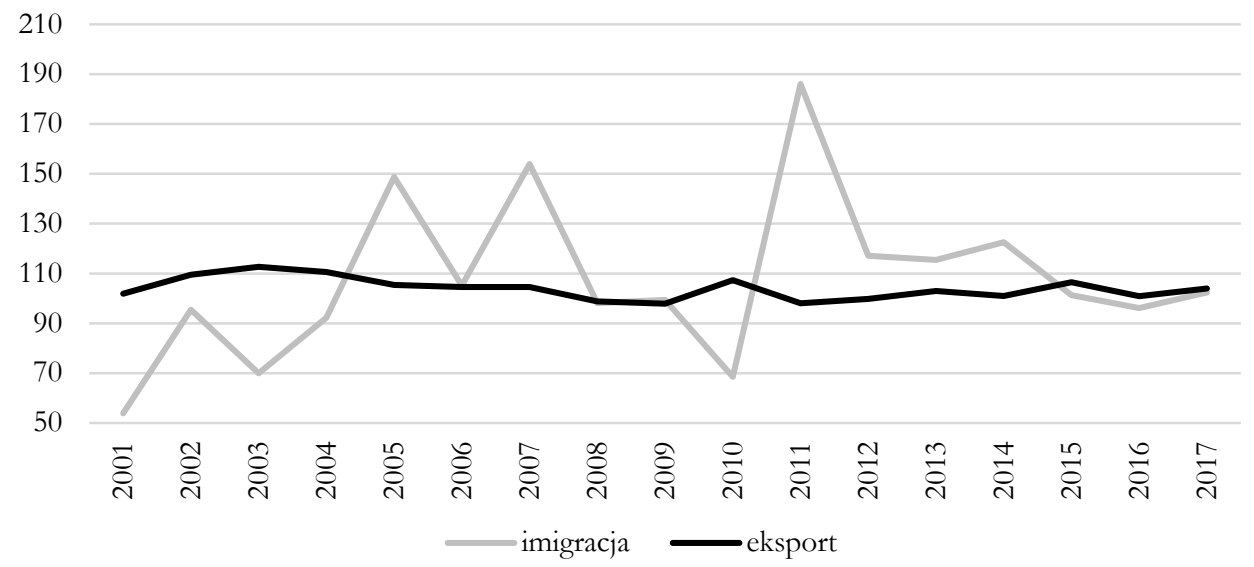

Źródło: opracowanie własne na podstawie [WTO, Rosstat]. 
W okresie objętym analizą relację między eksportem a emigracją częściowo wytłumaczyć można wykorzystując podstawową teorię H-O-S i wynikająca z niej tezę o substytucyjności wymiany handlowej i migracji (choć restrykcyjne założenia teorii utrudniaja moźliwość jej odniesienia do rzeczywistości gospodarczej). Znaczącej dynamice wolumenu eksportu towarzyszył spadek dynamiki emigracji, i odwrotnie: wraz ze spadkiem dynamiki eksportu emigracja nasilała się, co wskazuje, że praca może być eksportowana w dobrach podlegających wymianie. Z kolei spadek eksportu wraz z imigracją wyjaśnić można zmniejszeniem popytu na produkty rosyjskie ze strony krajów, z których pochodzą imigranci, skoro nabyć je moga przebywając w tym kraju.

Nieco odmiennie kształtuje się relacja między importem a migracjami. O ile w przypadku emigracji i importu (rysunek 3) wskazać można na podobne relacje jak między emigracją a eksportem, to relacja między importem a imigracją kształtuje się inaczej. W tym pierwszym zakresie zauważyć można, że niskiej dynamice emigracji towarzyszył wzrost dynamiki wolumenu importu (od 2001 do 2011 r., z wyjątkiem 2009 r.). W latach 2012-2017 natomiast (z wyjątkiem 2016 r.) rosnącej emigracji towarzyszył spadek dynamiki importu. Jednym z argumentów wyjaśniających taką relację jest zmniejszenie popytu na dobra (w tym dobra importowane) wraz z emigracją ludności.

RYSUNEK 3

\section{Dynamika wolumenu importu i dynamika emigracji z Rosji w latach 2001-2017 (indeks; rok poprzedni $=100$ )}

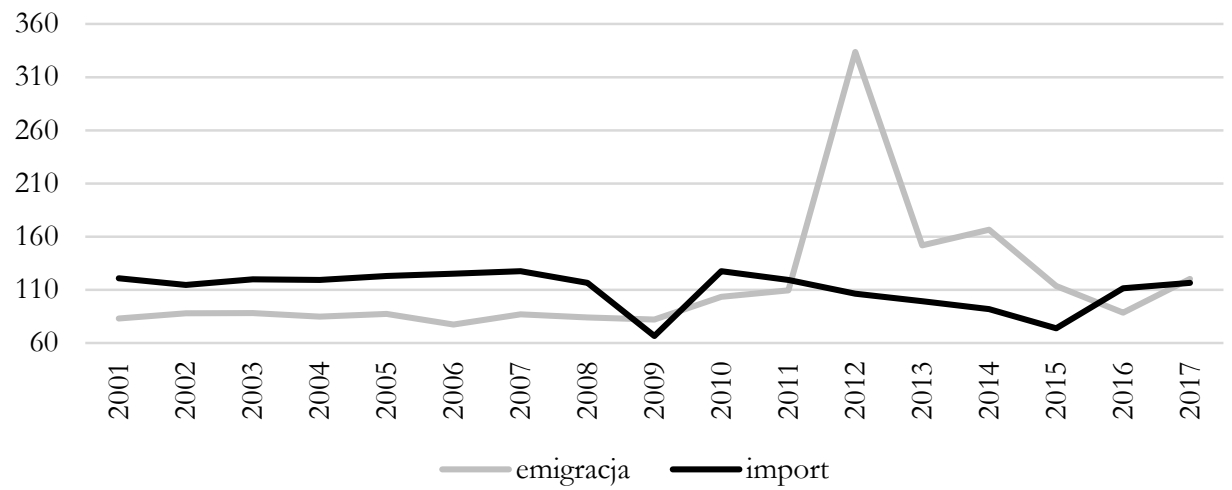

Źródło: opracowanie własne na podstawie [WTO, Rosstat].

Uznając, że spadek importu wynikać może z emigracji, jednocześnie spodziewać się można zwiększenia popytu (w tym na dobra importowane) na skutek imigracji. Przeprowadzona analiza relacji między importem a imigracja do Rosji potwierdza to założenie (rysunek 4).

Rosnącej dynamice imigracji towarzyszyła rosnąca dynamika wolumenu importu. Dodatkowo, jedynie w przypadku relacji między imigracją a importem wykazać można korelacje pozytywną (w poprzednich trzech relacjach korelacja była nega- 
tywna). Wyjaśnienie zależności między dynamiką importu a dynamiką imigracji oprzeć można na przytoczonych w punkcie drugim artykułu rozważaniach Genc’a, który wpływ imigracji na handel ujmuje w kontekście zmiany popytu na skutek zmiany populacji w kraju przyjmującym migrantów.

\section{Dynamika wolumenu importu i dynamika imigracji do Rosji w latach 2001-2017 (indeks; rok poprzedni $=100$ )}

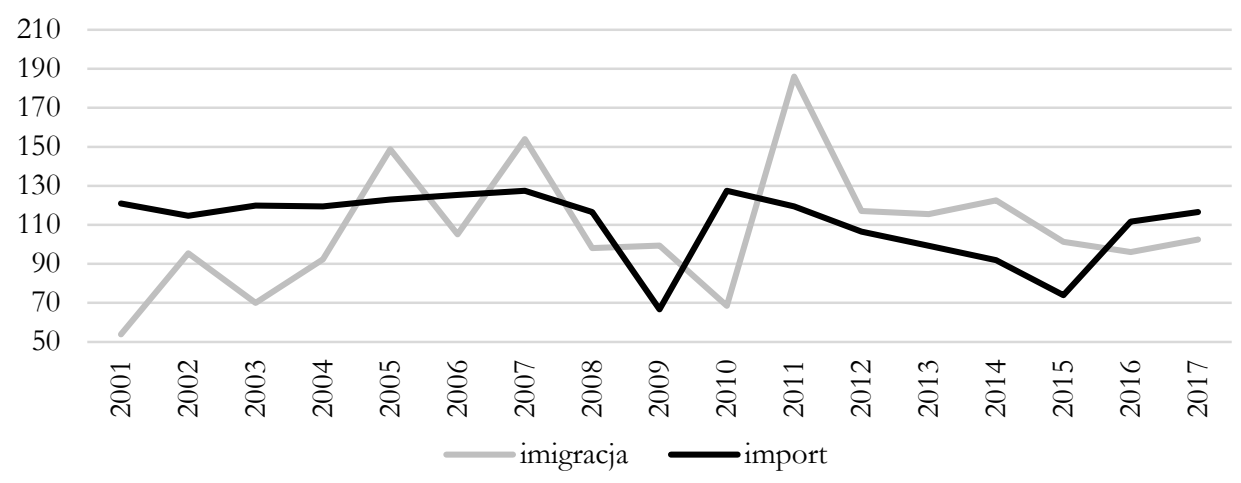

Źródło: opracowanie własne na podstawie [WTO, Rosstat].

Do prezentowanych danych należy odnosić się jednak z ostrożnością. Federacja Rosyjska, jako kraj docelowy imigrantów, wykazuje się określoną specyfiką. Rosyjski rynek pracy od początku lat 90 . stanowi główne miejsce docelowe dla potencjalnych pracowników z byłych republik radzieckich. Ponadto duże znaczenie w kontekście imigracji do Rosji odgrywa kryzys demograficzny, jaki ma miejsce w tym kraju. Już od 1992 r. rozpoczął się w Rosji trwały spadek rzeczywistej liczby ludności (bez uwzględniania migracji), który do 2012 r. wyniósł 13,2 mln osób. Z kolei systematyczny spadek ogólnej liczby ludności (z uwzględnieniem salda migracji) utrzymywał się w latach 1995-2008 i wyniósł 5,7 milionów osób [Rosstat, 2015, s. 15-16, 20-21]. Niekorzystne zmiany dotyczą też liczby ludności w wieku produkcyjnym. Według spisów powszechnych, na przestrzeni lat 2002-2014 zmniejszyła się ona z 88,9 mln do 85,2 mln. Imigracja postrzegana jest jako kluczowe źródło kompensowania spadku liczby ludności Rosji. Według szacunków w latach 90. XX w. i w ubiegłej dekadzie kompensowała od 50 do $80 \%$ rzeczywistego spadku populacji Rosji, natomiast w 2010 r. prawie całość spadku liczby ludności kraju [Рязанцев, 2012, s. 114].

Podkreślić należy również fakt, iż mimo liberalizacji przepływów pracy w ramach Euroazjatyckiej Unii Gospodarczej, jaka miała miejsce od 2012 r., największa dynamika wzrostu imigracji do Rosji po 2011 r. wystapiła w przypadku obywateli Ukrainy i Uzbekistanu, nienależących do tego ugrupowania. Jak wskazują dane dotyczące struktury geograficznej handlu zagranicznego Rosji, w przypadku tych krajów zaobserwować można również najbardziej znaczący spadek wartości eksportu do 
Rosji i importu z Rosji od 2010 r. (w porównaniu z innymi krajami WNP), co może potwierdzać wyniki przedstawionych badań, świadczące o substytucyjnej relacji między wymianą handlową a migracjami w przypadku Federacji Rosyjskiej [Rosstat, 2017a, s. 154-155].

\section{Podsumowanie}

Przeprowadzona analiza, choć nie wyczerpuje szerokiego zagadnienia relacji między międzynarodowym handlem a przepływem siły roboczej, pozwala na wyciagnięcie kilku wniosków. W pierwszej kolejności należy podkreślić, iż w świetle dokonanego przeglądu wybranych teorii i modeli handlu oraz dotychczasowych badań empirycznych relacja pomiędzy handlem a migracjami nie jest oczywista, zależy od wielu okoliczności, w których odbywa się wymiana handlowa. Jednocześnie zauważyć należy, iż przekonanie o substytucyjnym charakterze wymiany handlowej i migracji, które podnoszone jest w dyskusji politycznej (argument, że w drodze liberalizacji handlu dojdzie do zmniejszenia presji migracyjnej) może okazywać się błędne.

Przeprowadzone badania w zakresie relacji między wymianą handlową a migracjami w Federacji Rosyjskiej wskazują na złożone relacje między emigracja, imigracja, eksportem i importem. W przypadku eksportu - zarówno w relacjach z emigracja, jak i imigracja - analiza wskazuje na substytucyjną relację między zmiennymi. W przypadku relacji między importem a emigracja, wnioski o charakterze relacji sa podobne. Z kolei analiza zależności pomiędzy importem a imigracją wskazuje na ich komplementarność. Uzyskane wyniki wyjaśniono w oparciu o przeanalizowane modele i teorie handlu. Analiza wykazała zróżnicowane relacje pomiędzy wymianą handlową a migracjami w Federacji Rosyjskiej. Złożoność i wielopłaszczyznowość tych związków stanowiły jeden z impulsów do podjęcia badań w tym zakresie.

\section{Literatura}

Baudassé T., Montalieu T., Rabaud I., 2018, Migration and OECD service exports: an institutional perspective, Artykul prezentowany podczas 19th INFER Annual Conference in Bordeaux in June 2017, http://data.leo-univ-orleans.fr/media/ seminars/426/immigration-echanges-services-institutions-30juin2018-en.pdf [data wejścia: 26.02.2019].

Borjas G.J., 1989, Economic Theory and International Migration, "International Migration Review", vol. 23, no. 3, pp. 457-485, DOI 10.2307/2546424.

Bryant J., Genç M., Law D., 2005, Trade and Migration to New Zealand, 5th Congress of the European Regional Science Association: "Land Use and Water Management in a Sustainable Network Society", 23-27 August 2005, Amsterdam, The Netherlands, European Regional Science Association (ERSA), Louvain-laNeuve, https://www.econstor.eu/bitstream/10419/117498/1/ERSA2005_192. pdf [data wejścia: 26.02.2019]. 
Bruder J., 2004, Are Trade and Migration Substitutes or Complements? - The Case of Germany, 1970-1998, Working Paper, University of Rostock, Germany.

Collins W.J, O'Rourke K.H., Williamson J.G., 1997, Were Trade and Factor Mobility Subsitutes in History? NBER Working Paper Series, no. 6059, https://www.nber. org/papers/w6059.pdf [data wejścia: 26.02.2019].

Davis D.R., 1993, Trade liberalization and income distribution, NBER Working Paper 5693, https://www.nber.org/papers/w5693.pdf [data wejścia: 10.11.2018].

Delgado-Wise R., Márquez Covarrubias H., 2007, The Reshaping of Mexican Labor Exports under NAFTA: Paradoxes and Challenges, "International Migration Review”, vol. 41 (3), pp. 656-679, DOI: 10.1111/j.1747-7379.2007.00089.x.

Dunlevy J.A., Hutchinson W.K., 1999, The Impact of Immigration on American Import Trade in the Late Nineteenth and Early Twentieth Centuries, "The Journal of Economic History", vol. 59 (4), pp. 1043-1062, DOI: 10.1017/S002205070002413X.

Egger P.H., Ehrlich M., Nelson D.R., 2011, Migration and trade, CESifo Working Paper, no. 3467, https://www.econstor.eu/bitstream/10419/46357/1/6619030 28.pdf [data wejścia: 10.11.2018].

Genc M., Gheasi M., Nijkamp P., Poot J., 2011, The Impact of Immigration on International Trade: A Meta-Analysis, IZA Discussion Papers, no. 6145, http://ftp.iza. org/dp6145.pdf [data wejścia: 8.11.2018].

Girma S., Yu X., 2000, The Link between Immigration and Trade: Evidence from the UK, Centre for Research on Globalisation and Labour Markets Research Paper, no. 2000/23, https://www.nottingham.ac.uk/gep/documents/papers/2000/00-23. pdf [data wejścia: 26.02.2019].

Grimwade N., 2003, International Trade. New Patterns of Trade, Production \& Investment, Routledge, London-New York.

de Haas H., 2006, Turning the tide? Why 'development instead of migration' policies are bound to fail, International Migration Institute Working Papers, no. 2, https://www.imi. ox.ac.uk/publications/wp-02-06 [data wejścia: 10.11.2018].

Hatton T.J., Williamson J.G., 2009, Emigration in the long run: evidence from two global centuries, "Asian Pacific Economic Literature", vol. 23(2), pp. 17-28, DOI: 10. 1111/j.1467-8411.2009.01238.x.

IEP (Институт экономической политики имени Е.Т. ГайАара), 2016, Российская экономика в 2015 году. Тенденции и перспективвъ. (Взгпуск 37), https://www.iep.ru/ $\mathrm{ru} /$ publikatcii/publication/7902.html [data wejścia: 20.01.2018].

Jacks D.S., Tang J.P., 2018, Trade and Immigration 1870-2010, NBER Working Paper Series, no. 25010, DOI: 10.3386/w25010, https://www.nber.org/papers/ w25010 [data wejścia: 26.02.2019].

Krugman P.R., 1979, Increasing Returns, Monopolistic Competition, and International Trade, "Journal of International Economics", vol. 9 (4), pp. 469-479, DOI: 10.1016/ 0022-1996(79)90017-5.

Krugman P.R., Obsfeld M., 2007, Ekonomia mięrzynarodowa. Teoria i polityka - cæesśc 1, Wydawnictwo Naukowe PWN, Warszawa.

Lund H., 2009, Migration and Trade. Substitutes or complements?, Lund University, Lund. 
Mabrouk F., 2012, Les enjeux économiques de la migration internationale sur le développement des pays d'orgine, Univeristé Montesquieu - Bordeaux, Univeristé Tunis El Manar.

Martin P., 2003, Economic integration and migration: The Mexico - US case, WIDER Discussion Paper, no. 35, http://archive.unu.edu/hq/library/Collection/PDF_ files/WIDER/WIDERdp2003.35.pdf [data wejścia: 8.11.2018].

Martin P.L., 1993, Trade and Migration: The case of NAFTA, "Asian and Pacific Migration Journal”, vol. 2 (3), pp. 329-367, DOI: 10.1177/011719689300200306.

Melchor del Río A., Thorwarth S., 2007, Tomatoes or Tomato Pickers? Free Trade and Migration in the NAFTA Case, University of Heidelberg Discussion Paper Series, no. 429, https://www.uni-heidelberg.de/md/awi/forschung/dp429.pdf [data wejścia: 8.11.2018].

Mińska-Struzik E., 2004, Wspótczesna teoria handlu międrynarodowego wobec elespansji przedsiebiorstw miedzynarodowych, [w:] Teoria handlu miedzynarodowego a wspótczesna gospodarka śniatowa, Rynarzewski T. (red.), Zeszyty Naukowe Akademii Ekonomicznej w Poznaniu, nr 39, Poznań.

Mundell R.A., 1957, International Trade and Factor Mobility, "The American Economic Review", vol. 47, pp. 321-335.

Mundra K., 2005, Immigration and International Trade: A Semiparametric Empirical Investigation, "Journal of International Trade \& Economic Development", vol. 14(1), pp. 65-91, DOI: 10.1080/0963819042000333252.

Richards A., 1993, Does Trade Liberalization Influence Migration? Some Evidence from Developing Countries, Organisation for Economic Co-operation and Development, Paris.

Rosstat, Офичиальная статистика. Международная миграчия, http://www.gks.ru/ wps/wcm/connect/rosstat_main/

rosstat/ru/statistics/population/demography/\# [data wejścia: 9.11.2018].

Rosstat, 2015, Аемографический ежегодник России 2015, http://www.gks.ru/free_doc/ doc_2015/demo15.pdf [data wejścia: 6.11.2016].

Rosstat, 2017, Аемографический ежегодник России 2017, http://www.gks.ru/free_doc/ doc_2017/demo17.pdf [data wejścia: 27.02.2019].

Rosstat, 2017a, Торговля в России, http://www.gks.ru/free_doc/doc_2017/torg17. pdf [data wejścia: 27.02.2019].

Rotte R., Vogler M., 1998, Determinants of International Migration: Empirical Evidence for Migration from Developing Countries to Germany, IZA Discussion Papers, no. 12, Institute for the Study of Labor (IZA), Bonn, http://ftp.iza.org/dp12.pdf [data wejścia: 27.02.2019].

Рязанцев С., 2012, России нужна новая мирачионная политика, Миграционные процессы, Т. 10, № 1(28), январь-апремь.

Schiff M., 1994, How Trade, Aid and Remittances Affect International Migration, The World Bank Policy Research Working Paper, no. 1376, http://documents. worldbank.org/curated/en/186431468740990223/pdf/multi-page.pdf [data wejścia: 25.10.2017].

Schiff M., 1996, South-North Migration and Trade. A Survey, The World Bank Policy Research Working Paper, no. 1696, https://elibrary.worldbank.org/doi/abs/10. 
1596/1813-9450-1696 [data wejścia: 25.10.2017], DOI: 10.1596/1813-94501696.

Solimano A., 2001, International Migration and the Global Economic Order. An Overview, The World Bank Policy Research Working Paper, no. 2720, https://elibrary. worldbank.org/doi/pdf/10.1596/1813-9450-2720 [data wejścia: 25.10.2017].

Taylor E.J., 2006, International migration and economic development: puzzles and policies for LDCs; Keynote Address at thirty-ninth session Commission on Population and Development, United Nations, http://www.un.org/en/development/desa/ population/pdf/commission/2006/keynote/taylor.pdf [data wejścia: 13.03.2016].

Williamson J.G., 1997, Globalization and Inequality, Past and Present, The World Bank Research Observer, vol. 12 (2), pp. 117-135, DOI: 10.1093/wbro/12.2.117.

W'TO, Merchandise export and import volume indices, WTO Data Portal, http://data. wto.org/ [data wejścia: 27.02.2019]. 